\title{
Perilaku Kebersihan Diri (Personal Hygiene) Santri di Pondok Pesantren Wilayah Kabupaten Brebes akan Terwujud Jika Didukung dengan Ketersediaan Sarana Prasarana
}

\author{
Ahmad Zakiudin*), Zahroh Shaluhiyah $\left.{ }^{* *}\right)$ \\ *) Akademi Kererawatan Al-Hikmah 2 Brebes Jateng \\ Korespondensi: ariza_zakie@yahoo.co.id \\ **) Magister Promosi Kesehatan Universitas Diponegoro Semarang
}

\begin{abstract}
ABSTRAK
Untuk meningkatkan derajat kesehatan santri perlu adanya upaya untuk meningkatkan perilaku kebersihan perorangan dengan hasil akhir menurunnya angka kesakitan penyakit menular. Tujuan penelitian yaitu untuk mengetahui faktor-faktor yang mempengaruhi perilaku kebrsihan diri (personal hygiene) santri di pondok pesantren Wilayah Kabupaten Brebes. Penelitian ini merupakan penelitian kuantitatif, jenis penelitian explanatory research, dengan rancangan cross sectional. Jumlah populasi sebanyak 3.350 siswa SMP dan SMA yang berada di Pondok Pesantren di Wilayah Kabupaten Brebes santri. Sampel dalam penelitian diambil dengan menggunakan teknik pengambilan sampel secara Proportional Cluster Random Sampling sejumlah 293 santri di 4 pondok pesantren. Pengumpulan data dengan melakukan wawancara dan observasi. Hasil analisis univariat menggambarkan perilaku kebersihan diri santri di Pondok pesantren wilayah Kabupaten Brebes dengan kategori baik 42,0\%, lebih sedikit dibandingkan dengan kategori kurang baik 58,0\%. Hasil analisis bivariat menggunakan uji statistik dengan Chi-Square menunjukkan ada sembilan variabel yang berhubungan secara signifikan yaitu jenis kelamin responden, pengetahuan responden, ketersediaan peraturan tentang kebersihan diri responden, ketersediaan peraturan tentang kebersihan diri responden, pemberian sosialisasi atau informasi tentang kebersihan diri responden, dukungan pengasuh pondok pesantren, dukungan teman, dukungan tenaga kesehatan dan dukungan depag. Variabel yang paling dominan berpengaruh adalah ketersediaan sarana dan prasarana kebersihan diri $(\mathrm{OR}=10,335)$.
\end{abstract}

Kata kunci : Perilaku Kebersihan Diri, Santri, Pondok Pesantren.

\begin{abstract}
The Behavior Of Personal Hygiene Student at The Islamic Boarding School District in Brebes is Reached If The Availability of infrastructure and facilities of personal hygiene. To improve the health of students should be effort to improve personal hygiene behavior with the final result decrease morbidity rate of infectious disease. The aim of the studi is to analyze the factors that influence the personal hygiene students at the Islamic boarding school district Brebes. The study is quantitative and explanatory research with cross sectional approach. The population of the study is all of the junior and high school at the four Islamic boarding school as many as 3.350 students. Whereas samples were taken by Proportional cluster random sampling as many as 293 students. Data collection is taken by interviews and observations. The results of the univariate analysis describes that the behavior of personal hygiene students at the Islamic boarding school at Brebes District is good category (42,0\%), less than the unfabvorable category is 58,0\%. The results of bivariate analysis with Chi Square analysis showed that there are nine variables significantly associated. The variables are, gender, knowledge, availability of facilities and infrastructure of personal hygiene, availability regulations on personal hygiene, provision of information or dissemination, carer support boarding school, Support of friend, support health personel and support the ministry of religion. The most dominant factors that influence is the availability of facilities and infrastructure of personal hygiene (OR=10.335).
\end{abstract}

Keyword : personal hygiene behavior, students, cottage 


\section{PENDAHULUAN}

Budaya bersih merupakan cerminan sikap dan perilaku masyarakat dalam menjaga dan memelihara kebersihan pribadi serta lingkungan dalam kehidupan sehari-hari. Pondok Pesantren sebagai salah satu tempat pendidikan di Indonesia saat ini berjumlah kurang lebih 40.000. Penyakit menular berbasis lingkungan dan perilaku seperti tuberkulosis paru, infeksi saluran pernapasan atas, diare dan penyakit kulit masih merupakan masalah kesehatan yang juga dapat ditemukan di Pondok Pesantren. Menurut Departemen Kesehatan Republik Indonesia prevalensi skabies di Puskesmas seluruh Indonesia pada tahun 2008 adalah 5,6\%-12,95\% dan skabies menduduki urutan ketiga dari 12 penyakit tersering (Siswono, 2008). Data kesakitan skabies pada tahun 2008 tingkat Puskesmas se-Kota Semarang adalah 1100 kasus. $14,72 \%$ diantaranya terjadi pada balita (DKK Semarang, 2008).

Prevalensi penyakit skabies disebuah pondok pesantren di Jakarta mencapai 78,70\%, di wilayah Kabupaten Pasuruan sebesar $66,70 \%$ prevalensi penyakit skabies jauh lebih tinggi dibandingkan dengan prevalensi penyakit skabies di negara berkembang yang hanya 6-27\% atau prevalensi penyakit skabies di Indonesia sebesar 4,60-12,95\% saja, dengan prevalensi tertinggi pada anak usia sekolah dan remaja (Nugraheni, 2008).

Untuk meningkatkan derajat kesehatan santri perlu adanya upaya untuk meningkatkan pengetahuan santri tentang kesehatan secara umum, khususnya tentang penyakit menular sehingga diharapkan ada perubahan sikap serta diikuti dengan perubahan perilaku kebersihan perorangan dengan hasil akhir menurunnya angka kesakitan penyakit menular. Upaya peningkatan, pencegahan dan penanggulangan masalah penyakit menular dapat ditempatkan sebagai ujung tombak paradigma sehat untuk mencapai Indonesia sehat 2010 (Nugraheni, 2008).

PHBS adalah semua perilaku sehat yang dilakukan atas dasar kesadaran untuk menolong diri sendiri dan anggota keluarga dibidang kesehatan serta dapat berperan aktif dalam melaksanakan kegiatan-kegiatan kesehatan masyarakat (Depkes RI, 2010). Untuk meningkatkan PHBS kepada setiap orang bukan hal yang mudah namun membutuhkan proses untuk saling mempengaruhi, berinteraksi dan sosialisasi antar individu, kelompok serta memantau, menilai dan mengukur tingkat perkembangan dari semua tatanan. Oleh karena itu, pembinaan dan pemberdayaan PHBS dilakukan melalui pendekatan tatanan yaitu tatanan rumah tangga, tempat 
umum, tempat kerja dan sekolah (Dinkes Prov. Jateng, 2009).

PHBS tatanan pendidikan (sekolah) adalah untuk memberdayakan siswa, guru dan masyarakat lingkungan sekolah agar sadar, mau dan mampu untuk memelihara dan meningkatkan kesehatan, mencegah resiko terjadinya penyakit dan melindungi diri dari ancaman penyakit (Depkes RI, 2010). Sekolah selain sebagai tempat pembelajaran juga dapat menjadi ancaman penularan penyakit apabila tidak dikelola dengan baik, lebih dari itu anak pondok pesantren sangat rentan terhadap serangan penyakit sehingga penerapan PHBS di pondok pesantren yang salah satu indikatornya kebersihan diri (personal hygiene) menjadi kebutuhan yang mutlak agar dapat menjadikan kebiasaan/tradisi dalam kehidupan sehari-hari.

Jalur utama penularan berbagai penyakit adalah melalui tangan yang terkontaminasi bakteri, virus atau telur cacing, yang dapat menyebabkan kerentanan penyebaran berbagai penyakit seperti kecacingan, infeksi saluran pernafasan atas (ISPA) dan diare. Hasil analisis data Riset Kesehatan Dasar (Riskesdas) tahun 2007 menunjukkan secara nasional masih rendahnya kualitas kesehatan dan perilaku tidak sehat pada masyarakat. Tindakan responden yang selalu mencuci tangan pakai sabun setelah $\mathrm{BAB}$ dan $\mathrm{BAK}$ hanya $31,6 \%$, sedangkan responden yang kadang-kadang cuci tangan pakai sabun setelah BAB dan BAK sebesar 63,2\%. Tindakan responden tentang selalu mengganti baju setiap hari sebesar 52,6\%, sedangkan responden yang kadang-kadang mengganti baju setiap hari sebesar 47,4\% (Proverawati. A, 2012).

Status kesehatan dipengaruhi oleh beberapa faktor diantaranya adalah sikap seseorang dalam merespon suatu penyakit skabies pada umumnya merupakan jenis penyakit menular. Sikap santri sangat penting peranannya dalam pencegahan skabies di lingkungan asrama Pondok yang membutuhkan kebersihan perorangan serta perilaku yang sehat. Sikap yang dimiliki oleh santri diharapkan dapat berpengaruh terhadap perilaku mereka guna mencegah terjadinya skabies di lingkungan Pondok tempat mereka tinggal. Tidur bersama, pakaian kotor yang digantung atau ditumpuk di kamar merupakan salah satu contoh sikap yang dapat menimbulkan skabies. Pengetahuan yang cukup baik mengenai kebersihan perorangan tidaklah berarti bila tidak menghasilkan respon batin dalam bentuk sikap, sikap merupakan hal yang paling penting. Sikap dapat digunakan untuk memprediksikan tingkah laku apa yang mungkin terjadi, dengan demikian sikap dapat diartikan sebagai suatu predisposisi tingkah laku yang akan tampak aktual apabila kesempatan untuk mengatakan terbuka luas (Sriyusufi, 1996). 
Penularan scabies terjadi secara kontak langsung dan tidak langsung. Kontak secara langsung misalnya bersentuhan dengan penderita atau tidak langsung misalnya melalui handuk dan pakaian. Disamping itu skabies dapat berkembang pada kebersihan perorangan yang jelek, lingkungan yang kurang bersih, demografi status perilaku individu (Nugraheni. N, 2008).

Di negara tropik penyakit kulit masih menduduki tempat yang penting karena penderita cukup banyak. Indonesia adalah negara beriklim tropis. Iklim inilah yang mempermudah perkembangan bakteri, parasit, maupun jamur. Sebagian besar penduduk berada di pedesaan dengan sosial ekonomi relatif rendah, higiene sanitasi masih kurang, sehingga penyakit ini masih dominan (Santoso. L, 2000).

Setiap orang dapat terinfeksi oleh tungau skabies tanpa memandang umur, ras, atau jenis kelamin dan tidak mengenai status sosial dan ekonomi. Skabies masih sering dijumpai di berbagai rumah sakit di Indonesia. Angka kejadian skabies di kalangan santri pondok pesantren di desa Sudimoro, Kecamatan Turen, Wilayah Kabupaten Malang sangat tinggi yaitu 89,9\%, sedangkan di Wilayah Kabupaten Buru dari 10 penyakit terbanyak tahun 2004, penyakit skabies berada pada urutan keempat sebesar 30\% (Riskesdas, 2013).
Penelitian yang dilakukan oleh Muzakir menguraikan bahwa pengetahuan santri mengenai scabies ditularkan melalui pakaian $76,6 \%$, dilihat dari kebersihan diri santri yang menderita scabies mengganti bajunya satu kali dalam sehari $57,1 \%$, mencuci handuk dua minggu sekali 66,2 (Muzakir, 2008). Penelitian yang dilakukan oleh Heny Sasmita di pondok Pesantren di kota Surakarta menguraikan bahwa ada hubungan yang bermakna dengan kejadian skabies yaitu personal higiene yang meliputi: kebiasaan mandi, kebiasaan membersihkan tempat tidur, kebiasaan santri tidur dalam satu tempat tidur, kebiasaan memakai handuk bersama, mencuci pakaian, menyetrika pakaian, berganti pakaian, mencuci handuk (Sasmita. H, 2012).

Menurut Khotimah angka kejadian scabies di kalangan santri pondok Pesantren Nurul hikmah di desa Jatisawit Bumiayu Brebes terdapat 18,2\% dari 200 responden, $45,5 \%$ mempunyai tingkat pendidikan baik, 37,9\% mempunyai sikap sedang dan 15,2\% mempunyai personal hygiene buruk (Khotimah. K, 2006).

Salah satu pondok pesantren yang ada di Brebes adalah Pondok Pesantren Al Hikmah Brebes. Seperti halnya di pondok pesantren pada umumnya, penyakit skabies merupakan penyakit yang sering ditemukan. Hampir semua santri Pondok Pesantren Wilayah Kabupaten Brebes 
pernah menderita penyakit ini. Data hasil survei kesehatan santri di wilayah Pondok pesantren Darunajjah Tegal Munding Brebes tahun 2010 terhadap 80 responden ternyata diperoleh angka kesakitan $31,25 \%$, pondok pesantren Mambaul ulum Brebes tahun 2010 terdapat 90 santri diperoleh angka kesakitan 33,33\%, data pada bulan Oktober 2011, dari sampel 80 orang santri yang terkena skabies adalah 45 orang $(56,25 \%)$.

Berdasarkan latar belakang di atas maka perumusan masalah yang diangkat adalah faktor apa sajakah yang berpengaruh terhadap perilaku kebersihan diri (personal hygiene) pada santri di Pondok Pesantren Wilayah Kabupaten Brebes?

\section{METODE}

Jenis penelitian ini adalah penelitian kuantitatif analitik. Desain penelitian menggunakan rancangan cross-sectional. Populasi dalam penelitian ini adalah para santri Putra-Putri usia 13 - 18 tahun yang termasuk kelas 7 - 12 di Pondok Pesantren di Wilayah Brebes sebanyak 3350 santri dengan jumlah sampel sebesar 293 santri yang diambil dari 4 pondok pesantren di Wilayah Brebes dengan cara proportional cluster random sampling. Pondok pesantren dijadikan sebagai cluster. Variabel terikat dalam penelitian ini adalah perilaku kebersihan diri santri, sedangkan variabel bebasnya meliputi umur, jenis kelamin, tingkat pendidikan, pengetahuan, sikap, dukungan pengasuh ponpes, dukungan teman, dukungan nakes, dukungan tenaga depag, ketersediaan sarpras, ketersediaan peraturan, ketesediaan informasi. Data yang telah terkumpul dianalisis secara univariat dengan cara distribusi frekuensi. Analisis bivariat dengan cara tabulasi silang kemudian dilakukan analisis statistik menggunakan uji chi square kemudian dilanjutkan dengan analisis multivariat menggunakan multiple logistic regression.

\section{HASIL DAN PEMBAHASAN}

Hasil penelitian menunjukkan bahwa perilaku kebersihan diri santri di Pondok pesantren wilayah Kabupaten Brebes dengan kategori baik 42,0\%, lebih sedikit dibandingkan dengan kategori kurang baik 58,0\%.

Di pondok Pesantren kecenderungan tertular penyakit kulit sebab kurangnya kebersihan diri sangat tinggi. Penyebabnya adalah tinggal bersama dengan sekelompok orang seperti di pesantren memang berisiko mudah tertular berbagai penyakit kulit, khusunya penyakit scabies. Penularan terjadi bila kebersihan pribadi dan lingkungan tidak terjaga dengan baik. Masih ada pesantren yang tumbuh dalam lingkungan yang kumuh, tempat mandi dan WC yang kotor, 
lingkungan yang lembab, dan sanitasi yang buruk. Ditambah lagi dengan perilaku yang tidak sehat, seperti menggantung pakaian dalam kamar, tidak membolehkan santri wanita menjemur pakaian di bawah terik matahari, dan saling bertukar benda pribadi, seperti sisir dan handuk (Akmal. Dkk, 2013).

Dapat dikatakan bahwa santri telah mengetahui mana yang baik untuk kesehatan dirinya, tetapi dalam mewujudkannya dalam perilaku masih juga buruk. Hal ini disebabkan karena kebiasaan individu yang berbeda. Kemungkinan lain efesiensi untuk melakukan kebersihan diri kurang mendapat perhatian dari lingkungannya. Perilaku santri dalam melakukan kebersihan diri akan lebih mudah apabila santri tersebut mengetahui manfaat melakukan kebersihan diri, tahu cara melakukan kebersihan diri yang benar dan tahu akibat atau dampak apabila tidak melakukan kebersihan diri. Perilaku juga akan dipermudah apabila santri yang bersangkutan mempunyai sikap yang positif terhadap perilaku kebersihan diri (Notoatmodjo, 2010).

\section{Karakteristik Responden}

\section{Umur}

Hasil penelitian didapatkan bahwa perilaku responden dalam melakukan kebersihan diri kurang lebih banyak ditemukan pada kelompok santri yang berusia 16-18 tahun yaitu $61,7 \%$ dibandingkan dengan kelompok santri yang berusia 13-15 tahun yaitu 54,2\%. Adanya perubahan umur tidak berdampak adanya perubahan perilaku. Pada umur 1618 tahun seharusnya dapat berperilaku baik dibandingkan dengan umur 13-15 tahun.

Penelitian ini menunjukkan bahwa tidak ada hubungan yang signifikan antara umur responden dengan perilaku kebersihan diri pada santri di Pondok Pesantren Kabupaten Brebes dengan hasil uji Chi square didapatkan p.value $=0,232$ (p.value $>\alpha$ ). Sehingga dalam penelitian ini (faktor internal) untuk berperilaku positif pada santri khususnya faktor umur santri tidak terbukti.

Hasil penelitian ini sejalan dengan penelitian yang dilakukan oleh Linda Warni pada tahun 2010 dimana hasil penelitian terdahulu menunjukkan bahwa umur tidak berhubungan dengan perilaku murid sekolah dasar pada kesehatan gigi dan mulut. Ada kemujngkinan rendahnya perilaku untuk menggosok gigi banyak dipengaruhi oleh faktor lain seperti faktor internal mengenai pengetahuan siswa, serta faktor yang ada diluar diri siswa adalah sosio-ekonomi (pekerjaan orang tua) dan sarana menggosok gigi. Disamping itu hasil penelitian ini sejalan dengan hasil penelitian Hidayat (2011) yang menunjukkan bahwa tidak ada hubungan 
antara umur dengan perilaku kebersihan diri pada santri di pesantren Nurul Huda Desa Cibatu Kecamatan Cisaat Kabupaten Sukabumi (Hidayat, 2011).

\section{Jenis Kelamin Santri}

Pengertian jenis kelamin (seks) menurut Hungu (2007) adalah perbedaan antara perempuan dengan laki-laki secara biologis sejak seseorang lahir. Seks berkaitan dengan tubuh laki-laki dan perempuan, dimana laki-laki memproduksikan sperma, sementara perempuan menghasilkan sel telur dan secara biologis mampu untuk menstruasi, hamil dan menyusui.Perbedaan biologis dan fungsi biologis laki-laki dan perempuan tidak dapat dipertukarkan diantara keduanya, dan fungsinya tetap dengan laki-laki dan perempuan pada segala ras yang ada di muka bumi (Sudarma, 2008).

\section{Menurut Santrock}

mengemukakan bahwa istilah gender dan seks memiliki perbedaan dari segi dimensi. Isilah seks (jenis kelamin) mengacu pada dimensi biologis seorang laki-laki dan perempuan, sedangkan gender mengacu pada dimensi sosial-budaya seorang lakilaki dan perempuan (Santrock. J, 2002).

Berdasarkan hasil analisis univariat diperoleh gambaran bahwa sebagian besar responden berjenis kelamin perempuan yaitu $69,6 \%$, sedangkan sisanya $30,4 \%$ berjenis kelamin laki-laki. Perilaku kebersihan diri yang kurang lebih banyak dijumpai pada kelompok santri dengan jenis kelamin laki-laki (70,8\%) dibandingkan dengan kelompok santri dengan jenis kelamin perempuan $(52,5 \%)$. Sedangkan persentase perilaku kebersihan diri yang baik lebih banyak terdapat pada kelompok santri yang berjenis kelamin perempuan $47,5 \%$ dibandingkan dengan kelompok santri yang berjenis kelamin laki-laki 29,2\%. Hasil uji statistk diperoleh p.value $=0,000$, karena p.value $<\alpha$ maka Ha diterima, dan Ho ditolak, sehingga dapat diinterpretasikan bahwa ada hubungan yang signifikan antara jenis kelamin dengan perilaku kebersihan diri santri di Pondok pesantren di wilayah Kabupaten Brebes. Ditinjau dari hasil penelitian orang lain diperoleh bahwa hasil penelitian ini bertolak belakang dengan hasil penelitian Hidayat (2011) yang menyatakan bahwa tidak ada hubungan antara jenis kelamin dengan perilaku kebersihan diri santri di pesantren Nurul Huda Desa Cibatu Kecamatan Cisaat Kabupaten Sukabumi (Hidayat, 2011).

\section{Tingkat Pendidikan Santri}

Hasil analisis univariat menunjukkan bahwa separuh lebih $(53,2 \%)$ responden memiliki pendidikan SMA/MA sedangkan sisanya $(46,8 \%)$ berusia adalah SMP/Mts. Perilaku kebersihan diri yang kurang lebih banyak dijumpai pada kelompok santri 
yang berpendidikan SMA 53,2\% dibandingkan dengan kelompok santri dengan pendidikan SMP $46,8 \%$. Sedangkan secara uji statistik dengan menggunakan uji Chi Square Test diperoleh nilai $p_{\text {-value (continuity }}$ Correction $)$ sebesar $0,344 \quad\left(p_{\text {-value }}>0,05\right)$ maka dapat disimpulkan bahwa tidak ada hubungan antara pendidikan responden dengan perilaku kebersihan diri santri di Pondok Pesantren di Wilayah Kabupaten Brebes.

Hasil penelitian ini bertolak belakang dengan teori yang menyatakan bahwa pendidikan seseorang akan mempengaruhi tingkat pengetahuan. Pengetahuan tersebut berasal dari menuntut ilmu di lembaga pendidikan formal atau non formal berupa informasi dari media elektronik, media cetak, atau teman. Semakin tinggi pendidikan seseorang maka akan semakin mudah menerima sesuatu. Tingkat kesehatan seseorang dapat ditentukan oleh tingkat pengetahuan atau pendidikan dari orang tersebut, sehingga semakin baik tingkat pengetahuan seseorang maka tingkat kesehatan orang tersebut juga akan semakin baik, pengetahuan dapat diperoleh dari lingkungan sekitar seperti media elektronik, media cetak, dan penyuluhan dari petugas kesehatan (Notoatmodjo, 2003).

Penelitian yang mendukung dari hasil penelitian ini adalah penelitian yang dilakukan oleh Hidayat (2011) yang menyimpulkan bahwa tidak ada hubungan antara tingkat pendidikan dengan perilaku kebersihan diri santri di pesantren Nurul Huda Desa Cibatu Kecamatan Cisaat Kabupaten Sukabumi (Hidayat, 2011).

\section{Ketersediaan Sarana dan Prasarana}

Kesehatan Di Pondok Pesantren

Moenir (1992) mengemukakan bahwa sarana adalah segala jenis peralatan, perlengkapan kerja dan fasilitas yang berfungsi sebagai alat utama/pembantu dalam pelaksanaan pekerjaan, dan juga dalam rangka kepentingan yang sedang berhubungan dengan organisasi kerja. Pengertian yang dikemukakan oleh Moenir, jelas memberi arah bahwa sarana dan prasarana adalah merupakan seperangkat alat yang digunakan dalam suatu proses kegiatan baik alat tersebut adalah merupakan peralatan pembantu maupun peralatan utama, yang keduanya berfungsi untuk mewujudkan tujuan yang hendak dicapai.

Air merupakan hal yang paling esensial bagi kesehatan, tidak hanya dalam upaya produksi tetapi juga untuk konsumsi domestik dan pemanfatannya (minum, masak, mandi, dan lain -lain). Promosi yang meningkat dari penyakit -penyakit infeksi yang bisa mematikan maupun merugikan kesehatan ditularkan melalui air yang tercemar. Sedikitnya 200 juta orang terinfeksi melalui kontak dengan air yang 
terinvestasi oleh parasit. Sebagian penyakit yang berkaitan dengan air bersifat menular, penyakit-penyakit tersebut umumnya diklasifikasikan menurut berbagai aspek lingkungan yang dapat diintervensi oleh manusia (WHO, 2001). Menurut Habeahan Jariston, salah satu faktor penting yang berpengaruh pada praktik PHBS adalah fasilitas sanitasi yang tercermin dari akses masyarakat terhadap air bersih dan sanitasi dasar. Pada tahun 2002 presentasi rumah yang mempunyai akses terhadap air bersih yang layak dikonsumsi baru mencapai 50\% dan akses rumah tangga terhadap sanitasi dasar baru mencapai $63,5 \%$.

Berdasarkan hasil analisis univariat diperoleh gambaran bahwa sebagian besar responden $(58,0 \%)$ mengatakan bahwa sarana dan prasarana kebersihan diri di pondok pesantren adalah lengkap, sedangkan responden yang mengatakan sarana dan prasarana kebersihan diri di pondok pesantren kurang lengkap yaitu sebesar 42,0\%. Perilaku kebersihan diri yang kurang lebih banyak dijumpai pada kelompok santri yang memiliki sarana dan prasarana kebersihan diri kurang lengkap di pondok pesantren $87,8 \%$ dibandingkan dengan kelompok santri yang memiliki sarana dan rasarana kebersihan diri yang lengkap di pondok pesantren 36,5\%. Sedangkan persentase perilaku kebersihan diri yang baik lebih banyak terdapat pada kelompok santri yang memiliki sarana dan prasarana lengkap $63,5 \%$ dibandingkan dengan kelompok santri yang memiliki sarana dan prasarana kurang lengkap $12,2 \%$.

Hasil uji statistk diperoleh p.value $=$ 0,000, karena p.value $<\alpha$ maka Ha diterima, dan Ho ditolak, sehingga dapat diinterpretasikan bahwa ada hubungan yang signifikan antara ketersediaan sarana dan prasarana dengan perilaku kebersihan diri santri di Pondok pesantren di wilayah Kabupaten Brebes.

Berdasarkan hasil jawaban responden tentang ketersediaan sarana dan prasarana kebersihan diri di pondok pesantren ada beberapa hal yang perlu mendapatkan perhatian yaitu sebanyak $86,3 \%$ responden menyatakan bahwa di pondok pesantren tidak tersedia setrika untuk menyetrika pakaian santri, sebanyak $82,6 \%$ responden menyatakan bahwa di pondok pesantren tidak tersedia tempat tidur yang terpisah untuk masing-masing santri, sebanyak $76,1 \%$ rsponden menyatakan bahwa di pondok pesantren tidak tersedia media promosi PHBS seperti leaflet, sebanyak $68,6 \%$ responden menyatakan bahwa di pondok pesantren tidak tersedia sabun untuk cuci tangan, sebanyak 56,3\% respnden menyatakan bahwa di pondok pesantren tidak tersedia air mengalir yang bersih di wastafel untuk cuci tangan pakai sabun, sebanyak $44,7 \%$ responden 
menyatakan bahwa di pondok pesantren tidak tersedia handuk untuk setiap orang.

\section{Ketersediaan Peraturan-Peraturan tentang Kebersihan Diri}

Hasil analisis deskriftif diperoleh gambaran bahwa separuh lebih responden $(53,6 \%)$ menyatakan bahwa sudah tersedia peraturan tentang kebersihan diri, sedangkan responden yang menyatakan bahwa peraturan tentang kebersihan diri masih kurang tersedia di pondok pesantren yaitu sebesar 46,4\%. Hasil penelitian menunjukkan bahwa perilaku kebersihan diri yang kurang lebih banyak dijumpai pada kelompok santri yang ketersediaan peraturannya mengenai kebersihan dirinya kurang $68,4 \%$ dibandingkan dengan kelompok santri yang ketersediaan peraturan mengenai kebersihan dirinya baik 49,0\%. Sedangkan perilaku kebersihan diri yang baik lebih banyak terdapat pada kelompok santri yang ketersediaan peraturan mengenai kebersihan dirinya baik $51,0 \%$ dibandingkan dengan kelompok santri yang ketersediaan peraturan mengenai kebersihan dirinya kurang $31,6 \%$.

Hasil uji statistik dengan menggunakan uji Chi Square Test diperoleh nilai p-value (Continuity Correction) sebesar 0,001 ( $p$-value < 0,05), karena $p$-value $<\alpha$ maka Ha diterima, dan Ho ditolak sehingga dapat diinterpretasikan bahwa ada hubungan yang signifikan antara ketersediaan peraturan dengan perilaku kebersihan diri santri di Pondok Pesantren di Wilayah Kabupaten Brebes.

Pesantren Al-Mansur Darunnajah 3 sudah menerapkan beberapa aturan-aturan mengenai upaya menjaga lingkungan, khususnya masalah kebrsihan lingkungan di sekitar pesantren diantaranya adalah peraturan yang mewajibkan semua santri untuk membuang sampah pada tempatnya, kewajiban kerja bakti setiap hari jumat pagi, dan dilaksanakannnya piket kebersihan lingkungan dan membuadayakan perilaku kebersihan diri yang sehat. Respon santri sangat baik mengenai kebersihan baik perilaku kebersihan diri maupun kebersihan lingkungan (Muhtarom, 2014).

\section{Pemberian Informasi Sosialisasi /}

\section{Pendidikan tentang Kebersihan Diri}

Berdasarkan hasil analisis univariat diperoleh gambaran bahwa separuh lebih responden menyatakan bahwa telah dilakuan pemberian informasi/sosialisasi tentang kebersihan diri di pondok pesantren dengan baik yaitu sebesar $50,2 \%$. Sedangkan sisanya $49,8 \%$ responden mengatakan bahwa pemberian informasi/sosialisasi tentang kebersihan diri masih kurang di pondok pesantren. Hasil penelitian menunjukkan bahwa perilaku kebersihan diri yang kurang lebih 
banyak dijumpai pada kelompok santri yang kurang dalam pemberian informasi/sosialisasi tentang kebersihan diri 69,2\% dibandingkan dengan kelompok santri yang menerima informasi/sosialisasi tentang kebersihan diri dengan baik $46,9 \%$. Sedangkan perilaku kebersihan diri yang baik lebih banyak dijumpai pada kelompok santri yang dalam pemberian informasi/sosialisasi tentang kebersihan diri baik $53,13 \%$ dibandingkan dengan kelompok santri yang dalam pemberian informasi/sosialisasi tentang kebersihan diri kurang 30,8\%.

Hasil uji statistik dengan menggunakan uji Chi Square Test diperoleh nilai p-value (continuity Correction) sebesar 0,000 (p-value < $0,05)$, karena $p$-value $<\alpha$ maka $\mathrm{Ha}$ diterima, dan Ho ditolak sehingga dapat diinterpretasikan bahwa ada hubungan yang signifikan antara pemberian informasi/sosialisasi tentang kebersihan diri dengan perilaku kebersihan diri santri di Pondok Pesantren di Wilayah Kabupaten Brebes.

Hasil penelitian ini cenderung sesuai dengan pendapat para ahli (seperti Green, 1980; McKenzie, 2007; Notoatmodjo, 2005), yang dapat disimpulkan bahwa strategi promosi kesehatan merupakan determinan penting perilaku sehat dari masyarakat, keluarga dan individu. Secara kelembagaan, hasil penelitian ini menunjukkan kesamaan dengan ketetapan Committee on Health Education and Promotion terminology yang dikutip oleh McKenzie (2007), hasil Konferensi Internasional ke-4 tentang promosi kesehatan yang dikutip oleh Liliweri (2007), dan Ketetapan Departemen Kesehatan RI, yang menjadikan Strategi Promosi Kesehatan sebagai determinan penting dari perilaku sehat, dan menjadikan strategi promosi kesehatan sebagai program untuk meningkatkan perilaku sehat atau perilaku hidup bersih dan sehat dari masyarakat, keluarga dan individu (Green, 2000).

\section{Pengetahuan Santri tentang Kebersihan}

\section{Diri}

Hasil analisis deskriftif diperoleh gambaran bahwa sebagian besar responden memiliki pengetahuan yang baik tentang kebersihan diri yaitu sebesar $71,7 \%$, sedangkan yang memiliki pengetahuan cukup hanya $28,3 \%$. Hasil penelitian menunjukkan bahwa perilaku kebersihan diri yang kurang lebih banyak dijumpai pada kelompok santri yang memiliki pengetahuan yang cukup mengenai kebersihan diri (67,5\%) dibandingkan dengan kelompok santri yang memiliki pengetahuan yang baik tentang kebersihan diri $(54,3 \%)$. Sedangkan perilaku kebersihan diri yang baik lebih banyak terdapat pada kelompok santri yang memiliki pengetahuan baik $(45,7 \%)$ 
dibandingkan dengan kelompok santri yang memiliki pengetahuan cukup $(32,5 \%)$.

Pengetahuan merupakan hasil dari tahu dan ini terjadi setelah orang melakukan penginderaan terhadap sesuatu objek tetentu. Penginderaan melalui panca indera manusia. Pengetahuan atau kognitif merupakan domain yang sangat penting dalam membentu tindakan seseorang (Notoatmodjo S, 2013). Pengetahuan yang diperoleh seseorang akan menimbulkan pengertian dan pemahaman terhadap pengetahuan tersebut. Dengan memahami sesuatu hal yang dipelajari, seseorang akan dapat mengadakan penilaian. Penilaian ini dapat bersifat positif atau negative. Penilaian yang positif akan menimbulkan sikap positif pula yang pada akhirnya akan berpengaruh pada perilaku positif tehadap sesuatu yang dipelajari tersebut (Winkel. WS, 1986).

Dalam penelitian yang dilakukan oleh Taufik (2006) menunjukkan bahwa ada peningkatan yang bermakna pengetahuan pengungsi tentang pencegahan skabies yang dilihat dari segi promosi kesehatan. Tingkat pengetahuan mempunyai peran penting dalam pencegahan penyakit skabies, khususnya dalam lingkungan yang penduduknya padat dalam hal ini termasuk asrama. Beberapa penelitian telah meneliti mengenai hubungan tingkat pengetahuan dengan kejadian scabies seperti pada penelitian Muzakir tahun 2008 yang meneliti tentang faktor yang berhubungan dengan kejadaian penyakit scabies pada pesantren di Kabupaten Aceh Besar, didapatkan hubungan yang signifikan antara tingkat pengetahuan dengan kejadian skabies $(\mathrm{p}$-value $=0,000)$. Pada penelitian ini juga didapatkan bahwa santri yang memiliki pengetahuan kurang berpeluang menderita scabies 7,344 kali dibandingkan santri yang berpengetahuan baik, dan santri yang berpengetahuan sedang berisiko menderita scabies 1,049 kali dibandingkan dnegan santri yang berpengetahuan kurang (Muzakir, 2008).

Penelitian lain yang dilakukan oleh Ummul pada tahun 2011 yang meneliti tentang faktor-faktror yang berhubungan dengan kejadian scabies di pondok pesantren Darrul Khufadh di wilayah kerja Puskesmas kejuara Kabupaten Bone menjelaskan bahwa faktorfaktor yang brepengaruh terhadap kejadian scabies diantaranya tingkat pengetahuan (p.value=0,000), Praktik kebersihan diri (p.value $=0,000)$. Penelitian ini menjelaskan bahwa tingkat pengetahuan seseorang merupakan hal yang sangat penting yang berperan dalam terbentuknya tindakan seseorang mengenai suatu penyakit baik berupa deteksi diri hingga upaya terhadap pencegahan penyakit (Ummul. H, 2011). 
Peningkatan pengetahuan untuk santri selama menempati pondok telah banyak memperoleh informasi tentang kesehatan, diantaranya tentang penyakit kulit. Pendidikan kesehatan yang diberikan kepada santri ini disampaikan melalui kuliah singkat yang biasanya dilakukan setiap selesai shalat maghrib. Sebagai penyegaran terhadap informasi yang telah diperoleh dengan penekanan terhadap pengetahuan pencegahan lebih mendalam tentang penyakit skabies. Peningkatan pengetahuan santri memang tidak semata dipengaruhi proses pelaksanaan pendidikan kesehatan saja. WHO (1992) menyatakan faktor lain yag juga mempengaruhi antara lain motivasi, kebutuhan terhadap informasi, pengalaman/mengalami kecerdasan, guru, teman, buku dan media massa (Winkel, 1986).

Kurangnya pengetahuan terhadap penyakit skabies, sehingga menyebabkan cepatnya penularan skabies yang terjadi didalam lingkungan pesantren. Penularan skabies dalam kategori tinggi di dalam masyarakat, lingkungan keluarga, sekolahsekolah dalam hal ini termasuk pesantren yang santrinya terinfeksi skabies. Kerlinger (2003) menyatakan bahwa pengetahuan yang maksimal dalam waktu singkat sulit terjadi perubahan baik peningkatan ataupun penurunannya. Banyak faktor yang menjadi alasan diantaranya masyarakat kesulitan memperoleh informasi yang lebih banyak tentang sesuatu setelah informasi utama diperolehnya (Notoatmojo, 2003).

Analisis distribusi frekuensi terhadap jenis pertanyaan yang diberikan menunjukkan bahwa penyebab, tanda dan gejala skabies umumnya tidak diketahui oleh santri. Pengetahuan ini sebagian besar mereka peroleh dari pengalaman mengalami baik langsung pada dirinya maupun tidak langsung pada anggota keluarga atau tetangga. Werner and Bower (1986) menyatakan bahwa penyakit bila seseorang pernah mengalami penyakit atau sedang menderita, bila ada inforamasi yang berkaitan dengan penyakit yang ia derita maka akan lebih tertarik untuk mendengarkannya. Seperti halnya santri yang memiliki pengalaman menderita skabies baik diri atau kawannya serta anggota keluarganya memiliki ketertarikan lebih tinggi dalam mengikuti pendidikan atau penyuluhan yang disampaikan (Winkel, 1986).

\section{Sikap Santri Terhadap Kebersihan Diri}

Sikap adalah pandangan atau kecenderungan mental. Sikap (attitude) merupakan kecenderungan yang relatif manetap untuk bereaksi dengan cara baik atau buruk terhadap orang atau barang tertentu (Syah M, 2005).

Sikap sebagai produk dari proses sosialisasi dimana seseorang bereaksi 
dengan rangsangan yang diterimanya. Sikap merupakan respon yang muncul apabila individu dihadapkan pada stimulus yang menghendaki respon individual. Respon yang dinyatakan sebagai sikap didasari oleh proses evaluasi dari bentuk baik atau buruk, positif atau negatif, menyenangkan atau tidak menyenangkan, suka atau tidak suka, yang kemudian mengkristalkan sebagai potensi terhadap sesuatu objek sikap (Saefudin, 1999).

Hasil analisis univariat diperoleh gambaran bahwa bahwa separuh lebih responden memiliki sikap yang baik (53,9\%) terhadap kebersihan diri, sedangkan responden yang memiliki sikap yang kurang terhadap kebersihan diri sebesar 46,18\%. Hasil uji statistik dengan p.value $=0,052($ p.value $>\alpha)$ artinya tidak ada hubungan yang signifikan antara sikap dengan perilaku kebersihan diri pada santri di pondok pesantren wilayah Kabupaten Brebes. Jadi sikap bukan merupakan faktor yang ada hubungannya dengan perilaku santri.

Hal ini sesuai dengan teori yang dikemukakan Green tentang perubahan perilaku bahwa salah satu faktor yang mempengaruhi perilaku seseorang adalah faktor penguat (reinforcing factor). Faktor penguat ini merupakan faktor yang memperkuat perubahan perilaku seseorang sumber penguat tergantung pada tujuan, misalnya sikap santri terhadap kebersihan diri (Green, 2000).

Perawatan diri atau kebersihan diri (personal hygiene) dilakukan untuk mempertahankan kesehatan baik secara fisik maupun fsikologis. Pemenuhan perawatan diri dipengaruhi beberapa faktor, diantaranya: budaya, nilai sosial pada individu atau keluarga, pengetahuan tentang perawatan diri, serta persepsi terhadap perawatan diri (Hidayat. A, 2006).

\section{Dukungan Pengasuh Ponpes Terhadap}

\section{Kebersihan Diri}

Brooks

(2001) juga mendefinisikan pengasuhan sebagai sebuah proses yang merujuk pada serangkaian aksi dan interaksi yang dilakukan orangtua untuk mendukung perkembangan anak. Proses pengasuhan bukanlah sebuah hubungan satu arah yang mana orangtua mempengaruhi anak namun lebih dari itu, pengasuhan merupakan proses interaksi antara orangtua dan anak yang dipengaruhi oleh budaya dan kelembagaan sosial dimana anak dibesarkan. Pengasuhan merupakan proses yang panjang, maka proses pengasuhan akan mencakup 1) interaksi antara anak, orang tua, dan masyarakat lingkungannya, 2) penyesuaian kebutuhan hidup dan temperamen anak dengan orang tuanya, 3) pemenuhan tanggung jawab untuk membesarkan dan memenuhi kebutuhan 
anak, 4) proses mendukung dan menolak keberadaan anak dan orang tua, serta 5) proses mengurangi resiko dan perlindungan tehadap individu dan lingkungan sosialnya (Irwanto. E, 1997).

Hasil analisis univariat diperoleh gambaran bahwa bahwa separuh lebih responden $(50,2 \%)$ mengatakan bahwa pengasuh pondok pesantren kurang mendukung terhadap kebersihan diri para santri, sedangkan sisanya sebesar $49,8 \%$ responden mengatakan bahwa pengasuh pondok pesantren mendukung terhadap kebersihan diri para santri. Hasil uji statistik dengan menggunakan uji Chi Square Test diperoleh nilai $p$-value (continuity Correction) sebesar 0,002 (pvalue< 0,05) maka dapat disimpulkan bahwa ada hubungan antara dukungan pengasuh ponpes terhadap kebersihan diri dengan perilaku kebersihan diri santri di Pondok Pesantren di Wilayah Kabupaten Brebes.

\section{Dukungan Teman Terhadap}

\section{Kebersihan Diri}

Dukungan sosial yang bersumber dari teman sebaya dapat memberikan informasi terkait dengan hal apa yang harus dilakukan seseorang dalam upaya membentuk identitas dirinya, selain itu dapat pula memberikan timbal balik atas apa yang mereka lakukan dalam kelompok dan lingkungan sosialnya serta memberikan kesempatan bagi orang tersebut untuk menguji coba berbagai macam peran dalam menyelesaikan krisis guna membentuk identitas diri yang optimal. Junir dalam Cremers ((1989) menyatakan bahwa, identitas diri akan timbul setelah krisis diselesaikan dan diakhiri dengan baik. Dukungan sosial dari teman sebaya dapat memberikan pengaruh terhadap pembentukan identitas diri pada seseorang. Hal ini sesuai dengan pendapat Sullivan dalam Manan (1993) dan Johnson \&Johnson (dalam Elleny (2007) teman sebaya bagi seseorang khususnya remaja mempunyai arti psikologis yang penting, karena selain sebagai wadah diskusi teman sebaya juga dapat merupakan sumber dukungan sosial yang penting bagi proses pembentukan identitas diri seseorang tersebut. Pernyataan ini juga dipertegas oleh Erikson (dalam Sprinthall \& Collins, 1995) yang mengatakan bahwa, pemberian dukungan sosial dan penyediaan tempat untuk melakukan segala uji coba membuat teman sebaya merupakan bagian yang penting dalam pembentukan identitas dirinya (Brook. J, 2012).

$$
\text { Hasil analisis deskriftif }
$$
menunjukkan bahwa separuh lebih responden $(50,5 \%)$ mengatakan bahwa teman mendukung terhadap kebersihan diri para santri, sedangkan sisanya sebesar $49,5 \%$ responden mengatakan bahwa teman masih kurang mendukung terhadap kebersihan diri para santri. Hasil uji 
statistk diperoleh p.value $=0,000$, karena p.value $<\alpha$ maka Ha diterima, dan Ho ditolak, sehingga dapat diinterpretasikan bahwa ada hubungan yang signifikan antara dukungan teman dengan perilaku kebersihan diri santri di Pondok pesantren di wilayah Kabupaten Brebes.

Pondok pesantren adalah sekolah Islam berasrama dan pendidikan umum yang persentase ajarannya lebih banyak ilmu-ilmu pendidikan agama Islam daripada ilmu umum. Para pelajar pesantren disebut sebagai santri, para santri biasanya tinggal di asrama yang disediakan oleh pesantren, santri akan tinggal bersama-sama dengan teman-teman dalam satu asrama, kehidupan berkelompok yang akan dijalani dengan berbagai macam karakteristik para santri dan dalam kehidupan berkelompok masalah yang dihadapi adalah pemeliharaan kebersihan, yaitu kebersihan kulit, kebersihan tangan dan kuku, kebersihan genitalia, kebersihan kaki, kebersihan lingkungan dan kebersihan pakaian. Perilaku hidup bersih dan sehat terutama kebersihan perseorangan di Pondok Pesantren pada umumnya kurang mendapat perhatian dari santri (Dhofir. Z, 2011).

Dukungan Tenaga Kesehatan Terhadap Kebersihan Diri

Hasil analisis univariat menunjukkan bahwa separuh lebih responden $(52,24 \%)$ mengatakan bahwa tenaga kesehatan mendukung terhadap kebersihan diri para santri, sedangkan sisanya sebesar $47,8 \%$ responden mengatakan bahwa tenaga kesehatan masih kurang mendukung terhadap kebersihan diri para santri. Hasil uji statistk diperoleh p.value $=0,000$, karena p.value $<\alpha$ maka Ha diterima, dan Ho ditolak, sehingga dapat diinterpretasikan bahwa ada hubungan yang signifikan antara dukungan tenaga kesehatan dengan perilaku kebersihan diri santri di Pondok pesantren di wilayah Kabupaten Brebes.

Green (2000) menyatakan bahwa faktor yang menentukan terjadinya perubahan perilaku adalah faktor reinforcing atau faktor penguat. Dimana yang termasuk dalam faktor tersebut salah satunya adalah dukungan tenaga kesehatan. Dukungan tenaga kesehatan dalam melakukan suatu tindakan akan memperkuat terjadinya seseorang untuk melakukan sebagaimana yang diinginkan oleh petugas kesehatan. Terjadinya perubahan perilaku tersebut juga bisa terjadi karena adanya dukungan masyarakat, dukungan praktisi promosi kesehatan dan pendidik kesehatan (Green 2000).

\section{Dukungan Tenaga Depag Terhadap} Kebersihan Diri

Hasil analisis univariat menunjukkan bahwa bahwa separuh lebih responden $(52,9 \%)$ mengatakan bahwa 
Depag mendukung terhadap kebersihan diri para santri, sedangkan sisanya sebesar $47,1 \%$ responden mengatakan bahwa Depag masih kurang mendukung terhadap kebersihan diri para santri. Hasil penelitian menunjukkan bahwa perilaku kebersihan diri yang kurang lebih banyak dijumpai pada kelompok santri yang kurang mendapat dukungan dari depag tentang kebersihan diri $61,6 \%$ dibandingkan dengan kelompok santri yang mendapat dukungan dari depag tentang kebersihan dirinya baik $54,8 \%$. Sedangkan perilaku kebersihan diri yang baik lebih banyak dijumpai pada kelompok santri yang mendapat dukungan dari depag tentang kebersihan diri $45,2 \%$ dibandingkan dengan kelompok santri yang kurang mendapat dukungan dari depag tentang kebersihan diri 38,4\%. Hasil uji statistik dengan menggunakan uji Chi Square Test diperoleh nilai p-value (continuity Correction) sebesar 0,013 ( $p$-value $<0,05)$ karena p-value $<\alpha$ maka Ha diterima, dan Ho ditolak maka dapat disimpulkan bahwa ada hubungan antara dukungan depag terhadap kebersihan diri dengan perilaku kebersihan diri santri di Pondok Pesantren di Wilayah Kabupaten Brebes.

Teori yang mendukung hasil penelitian ini adalah bahwa norma-norma subyektif, norma social mengacu pada keyakinan seseorang terhadap bagaimana dan apa yang dipikirkan orang-orang yang dianggapnya penting (referent person) dan motivasi seseorang untuk mengikuti pikiran tersebut (Glanz. K and Rimer KB, 2008).

Faktor yang Paling Dominan Berpengaruh terhadap Perilaku Kebersihan Diri

Hasil analisis multivariat menunjukkan bahwa terdapat 3 (tiga) variabel bebas yang terbukti berpengaruh secara bersama-sama terhadap perilaku kebersihan diri santri di Pondok Pesantren Di Wilayah Kabupaten Brebes. Adapun variabel yang berpengaruh tersebut adalah jenis kelamin, ketersediaan sarana prasarana tentang kebersihan diri di pondok pesantren, dan dukungan teman tentang kebersihan diri karena semuanya mempunyai $\mathrm{p}$ value $<0,05$. Dari ketiga variabel bebas tersebut variabel ketersediaan sarana dan prasarana kebersihan diri yang berpengaruh paling dominan terhadap perilaku kebersihan diri santri dengan nilai OR sebesar 10,335 dan nilai signifikansi $0,000<0,05$, kemudian dukungan teman tentang kebersihan diri dengan nilai OR sebesar 2,508 dan nilai signifikansi 0,001<0,05. Makna kontribusi masing- masing variabel yang signifikan dalam analisis multivariat adalah sebagai berikut santri yang memiliki ketersediaan sarana dan prasarana tidak lengkap akan memungkinkan memiliki perilaku kebersihan diri yang kurang sebesar 10,335 
kali dibanding dengan santri yang memiliki ketersediaan sarana dan prasarana kebersihan diri di pondok pesantrennya lengkap, santri yang kurang mendapat dukungan dari temannya tentang kebersihan diri memungkinkan memiliki perilaku kebersihan diri yang kurang sebesar 2,508 kali dibanding dengan santri yang mendapat dukungan dari temannya.

Moenir (1992) mengemukakan bahwa sarana adalah segala jenis peralatan, perlengkapan kerja dan fasilitas yang berfungsi sebagai alat utama/pembantu dalam pelaksanaan pekerjaan, dan juga dalam rangka kepentingan yang sedang berhubungan dengan organisasi kerja. Pengertian yang dikemukakan oleh Moenir, jelas memberi arah bahwa sarana dan prasarana adalah merupakan seperangkat alat yang digunakan dalam suatu proses kegiatan baik alat tersebut adalah merupakan peralatan pembantu maupun peralatan utama, yang keduanya berfungsi untuk mewujudkan tujuan yang hendak dicapai.

Green (2000) menyatakan bahwa yang termasuk dalam faktor pemungkin yaitu ketersediaan sarana kesehatan, ketersediaan sarana transportasi akan berdampak pada respon masyarakat untuk berpartisipasi dalam programprogram kesehatan. Disamping itu faktor pemungkin seperti keahlian seseorang, organisasi atau masyarakat akan mengakibatkan terjadinya perubahan perilaku dan lingkungan (Green, 2000).

\section{SIMPULAN}

Perilaku kebersihan diri santri di Pondok pesantren wilayah Kabupaten Brebes dengan kategori baik 42,0\%, lebih sedikit dibandingkan dengan kategori kurang baik 58,0\%. Ketersediaan sarana dan prasarana tentang kebersihan diri, dengan odds ratio 10,335. Artinya ketersediaan sarana dan prasarana yang lengkap mempunyai kemungkinan santri untuk berperilaku melakukan kebersihan diri yang baik sebanyak 10,335 kali lebih besar dibandingkan dengan santri yang ketersediaan sarana dan prasarananya kurang lengkap.

\section{KEPUSTAKAAN}

Akmal, dkk. Hubungan Personal Hygiene dengan Kejadian Skabies Di Pondok Pendidikan Islam Darul Ulum. Palarik Air Pacah. Kecamatan Koto Tangah Padang. Jurnal Kesehatan Andalas. 2013; 2 (3) : (1-4).

Brooks J. The Process of Parenting $\left(8^{\text {th }}\right)$. Pustaka Pelajar. Yogyakarta. 2012. Departemen Kesehatan RI. Pedoman Program Perilaku Hidup Bersih dan Sehat. Departemen Kesehatan RI. Jakarta. 2010.

Dinas Kesehatan Provinsi Jawa Tengah. Pengembangan Perilaku Hidup 
bersih Dan Sehat Di Lima Tatanan.

Dinas Kesehatan Provinsi Jawa

Tengah. Semarang. 2009.

Dinas Kesehatan Kota (DKK) Semarang.

Rekapitulasi Tahunan Data

Kesakitan Tingkat Puskesmas Se-

Kota Semarang. DKK Semarang.

Semarang. 2008.

Dhofir Z. Tradisi Pesantren Ditinjau dari

Kehidupan Kyai (Cetakan

Kesembilan). Lembaga Penelitian

Pendidikan dan Penerangan

Ekonomi dan Sosial (LP3ES).

Jakarta. 2011.

Green L and Kreuter W. Health Promotion

Planning an Educational and Environmental Approach. (

Second Edition). Mayfield

Publising Company. London. 2000.

Glanz K and Rimer KB. Health Behavior and Health Education; Theory Research and Practice. Jossey-Bass A Wiley Company. San Fransisco. 2008.

Hidayat T. Faktor-Faktor yang Berhubungan dengan Kebersihan Diri dan Kesehatan Lingkungan Di Pesantren Nurul Huda Desa Cibatu Kecamatan Cisaat Kabupaten Sukabumi. Fakultas Kesehatan Masyarakat. Universitas Indonesia. Jakarta. 2011.
Hidayat A. Pengantar Kebutuhan Dasar Manusia. Salemba Medika. Jakarta 2006.

Irwanto E, dkk. Psikologi Umum. Gramedia Pustaka Utama. Jakarta. 1997.

Khotimah K. Beberapa Faktor Yang Berhubungan Dengan kejadian Skabies Di Pondok Pesantren Nurul Hikmah Jatisawit Bumiayu Brebes. Magister Promosi Kesehatan Fakultas Kesehatan Masyarakat Universitas Diponegoro. Semarang. 2006.

Muhtarom. Pembinaan Kesadaran Lingkungan Hidup di Pondok Pesantren : Studi Kasus di Pondok Pesantren Al-Mansur Darunnajah 3 Kabupaten Serang. Jurnal Kebudayaan Islam. 2014; 12 (2) : (1-16).

Muzakir. Faktor-Faktor Yang Berhubungan dengan Kejadian Penyakit Skabies Pada Pesantren di Kabupaten Aceh Besar. Sekolah Pascasarjana Universitas Sumatra Utara. Medan. 2008.

Notoatmodjo S. Promosi Kesehatan dan Ilmu Perilaku. Rineka Cipta. Jakarta. 2003.

Notoatmodjo S. Pendidikan dan Perilaku Kesehatan Masyarakat. Rineka Cipta. Jakarta. 2003. 
Nugraheni N. Pengaruh Sikap Tentang Kebersihan Diri Terhadap Scabies Pada Santri Al Muayyad Surakarta. Fakultas Ilmu Kesehatan Universitas Muhammadiyah Surakarta. Surakarta. 2008.

Proverawati, A. Perilaku Hidup Bersih dan Sehat. Nuha Medika. Jakarta. 2012.

Saefudin A. Penyusunan Skala Psikologi. Pustaka Pelajar. Yogyakarta 1999.

Santoso L. Pengantar Entomologi Kesehatan. Fakultas Kesehatan Masyarakat Universitas Diponegoro. Semarang. 2000.

Santrock J. Perkembangan Masa Hidup. Erlangga. Jakarta 2002.

Syah, M. Psikologi Pendidikan dengan Pendekatan Baru. Rosdakarya. Bandung. 2005.

Sasmita H. Hubungan Pesrsonal Hygiene dengan Kejadian Skabies di Pondok Pesantren Ta'mirul Islam di Kota Surakarta. Program Pascasarjana Fakultas Kedokteran Universitas Gadjah Mada. Yogyakarta. 2012.

Siswono. Pedoman Umum Program Pemberantasan Penyakit
Lingkungan.

Departemen

Kesehatan RI. Jakarta. 2008.

Sriyusufi I. Perbedaan Kondisi Sanitasi Pondok Pesantren terhadap Timbulnya Penyakit Kulit di Asrama Pondok Pesantren Yayasan Futuhiyya Mranggen Demak. Fakultas Kesehatan Masyarakat Universitas Diponegoro.

Semarang.1996.

Ummul H. Faktor yang Berhubungan dengan Kejadian Scabies di Pondok Pesantren Darul Khuffadh di Wilayah Kerja Puskesmas Kajuara Kabupaten Bone. Jurnal Media Kedokteran. 2011; 2 (4) : (110).

Widiati S. Planet Kita Kesehatan Kita (Terjemahan). Universitas Gadjah Mada. Yogyakarta. 2001.

Winkel WS. Psikologi Pendidikan dan Evaluasi Belajar. Gramedia Pustaka Utama. Jakarta 1983. 